\title{
Chironomid-based palaeotemperature estimates for northeast Finland during Oxygen Isotope Stage 3
}

\author{
S. Engels $\cdot$ S. J. P. Bohncke $\cdot$ J. A. A. Bos $\cdot$ \\ S. J. Brooks · O. Heiri · K. F. Helmens
}

Received: 1 April 2007/ Accepted: 24 June 2007 / Published online: 2 October 2007

(C) Springer Science+Business Media B.V. 2007

\begin{abstract}
Quantitative palaeotemperature estimates for the earlier part of Oxygen Isotope Stage (OIS-) 3 are inferred from subfossil chironomid remains. The high-latitudinal study site of Sokli, northeast Finland, provides for a unique lacustrine deposit covering the earlier part of OIS-3, and the chironomid remains found in the sediments show that a shallow lake with a diverse fauna was present at the study site throughout the record. Using a Norwegian calibration data set as a modern analogue, mean July air temperatures are reconstructed. The chironomidinferred July air temperatures are surprisingly high, reaching values similar to the current temperature at
\end{abstract}

S. Engels $(\varangle)$ - S. J. P. Bohncke · J. A. A. Bos Department of Paleoclimatology and Geomorphology, Faculty of Earth and Life Sciences, Vrije Universiteit, De Boelelaan 1085, Amsterdam 1081 HV,

The Netherlands

e-mail: stefan.engels@falw.vu.nl

\section{S. J. Brooks}

Department of Entomology, The National History

Museum, Cromwell Road, London SW7 5BD, UK

O. Heiri

Palaeoecology, Laboratory of Palaeobotany and Palynology, Institute of Environmental Biology, Utrecht University, Budapestlaan 4, Utrecht 3584 CD, The Netherlands

\section{K. F. Helmens}

Department of Physical Geography \& Quaternary Geology, Stockholm University, Stockholm 106 91, Sweden the study site. Other proxies that were applied to the sediments included the analysis of botanical and zoological macro-remains, and our results concur with temperature estimates derived from climate indicator taxa. Summer temperatures for interstadial conditions, reconstructed with climate models, are as high as our proxy-based palaeotemperatures.

Keywords Chironomids - Oxygen Isotope Stage 3 . Climate change $\cdot$ Summer temperature .

Northeast Finland

\section{Introduction}

There is ample evidence from marine and ice corerecords for the existence of abrupt climate oscillations, the so-called Dansgaard/Oeschger (D/O) events, during Oxygen Isotope Stage (OIS)-3 (Johnsen et al. 1992; Dansgaard et al. 1993; Voelker et al. 2002). The mechanisms driving these abrupt and dramatic climate shifts are still poorly understood. An important step towards understanding these mechanisms is to analyze the global or hemispheric signature of the climate shifts associated with $\mathrm{D} / \mathrm{O}$ events, for which quantitative information from a range of archives and for different regions including the ice-sheets, the marine realm, and the terrestrial realm is needed. However, the scarcity of terrestrial records dating back to OIS-3, which document palaeoenvironmental change on a local or regional 
scale, presently prevents correlation between the marine and ice core records and the terrestrial archives.

Continuous high-resolution terrestrial records from the European continent, which show climatic trends similar to the ice core and marine records, are sparse and are found only in southerly locations where stadial and interstadial periods are registered in pollen-records (e.g. De Beaulieu and Reille 1992). In central and northwestern Europe, only a limited number of sequential interstadial records have been recognized (e.g. Van der Hammen et al. 1967; Huijzer and Vandenberghe 1998). Terrestrial climate records from high-latitudinal regions of Europe and dating back to the last glacial are, because of the past existence of an extensive ice-sheet, virtually nonexistent. This absence is especially unfortunate since high-latitudinal regions are considered to be most affected by climate change (e.g. Cubasch et al. 2001).

The Sokli study-site, situated in northeast Finland, consists of a small basin with atypical bedrock conditions. The exceptional geological setting provides for a sedimentary basin where the deposits show a sequence of several fossil-rich interstadial sediments (Helmens et al. 2000, 2007). Finely laminated lacustrine deposits dated to the early part of OIS-3 provide a unique opportunity to study the local environmental changes through the analysis of a range of different proxies.

Chironomids (or non-biting midges) are recognized as a powerful proxy for inferring past climatic changes (e.g. Walker et al. 1991; Brooks and Birks 2001; Barley et al. 2006) and have been widely used to infer quantitative mean July air temperatures on both late-glacial and Holocene timescales (e.g. Ilyashuk et al. 2005; Brooks 2006; Walker and Cwynar 2006). Other studies used fossil chironomid assemblages in order to quantitatively reconstruct lakewater salinity (e.g. Eggermont et al. 2006), hypolimnetic oxygenation (Quinlan and Smol 2001) or trophic conditions in lakes (Woodward and Shulmeister 2006).

Quantitative palaeoclimatic inferences can contribute to our understanding of climate dynamics and forcing mechanisms (e.g. Vandenberghe et al. 1998), as well as serving to validate climate models (e.g. Cane et al. 2006; Kageyama et al. 2006). Here we present the results of a detailed chironomid analysis of high-latitudinal lacustrine sediments, covering the earlier part of OIS-3, and palaeotemperature estimates for a time-interval where such quantitative data are sparse.

\section{Site description and materials}

Sokli study-site

The Sokli study-site $\left(67^{\circ} 48^{\prime} \mathrm{N}, 29^{\circ} 18^{\prime} \mathrm{E}\right)$ is situated in the northeastern part of Finnish Lapland (Fig. 1). The current mire system stretches along the Sokli rivulet for a length of approximately $15 \mathrm{~km}$ (Helmens et al. 2000), and is situated at an altitude of approximately $220 \mathrm{~m}$ a.s.l. Gently sloping hills, which reach an elevation of about $300-350 \mathrm{~m}$, surround this mire and rivulet system (Helmens et al. 2000). The area is currently situated in the northern boreal forest

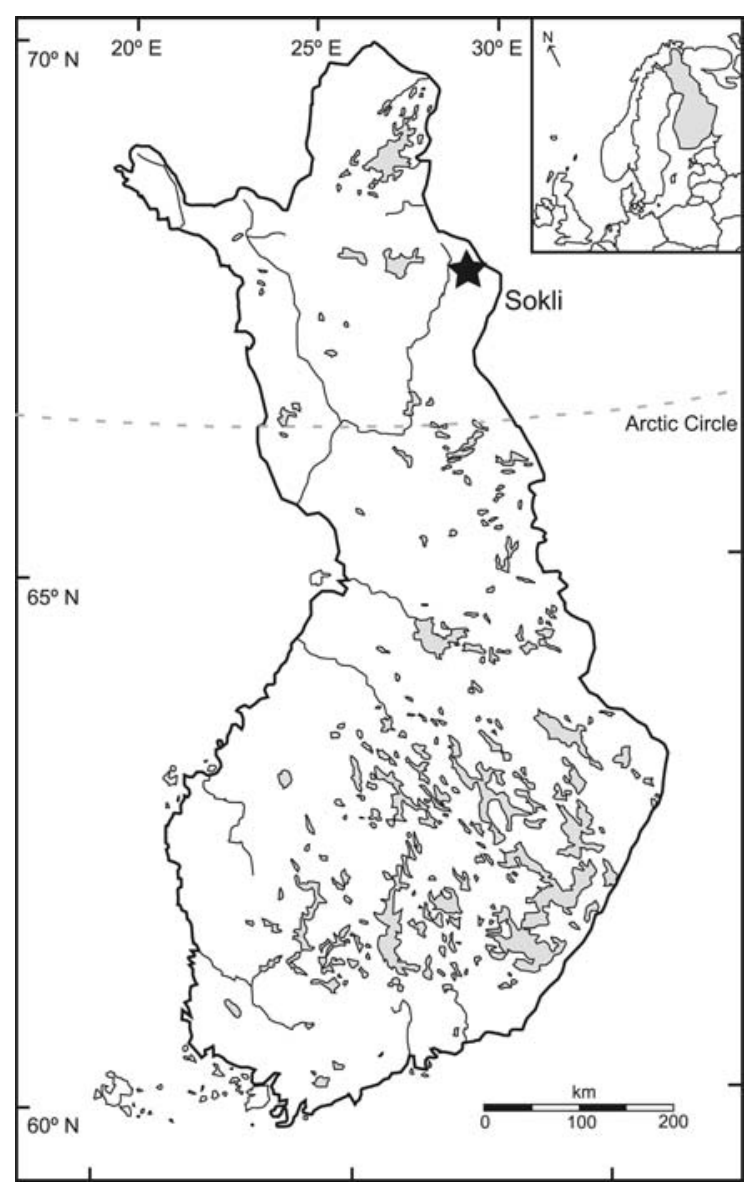

Fig. 1 Location map of Finland with major rivers and lakes, and the location of the Sokli site (asterisk) 
dominated by birch (Betula), spruce (Picea) and pine (Pinus), and the coring site itself is characterized by a vegetation consisting mainly of sedges (mostly Carex). The present climate in the region is "cold temperate", having a mean July air temperature of $13-14^{\circ} \mathrm{C}$ and a mean February temperature of $-14^{\circ} \mathrm{C}$. Annual precipitation averages between $500 \mathrm{~mm}$ and $550 \mathrm{~mm}$ (Drebs et al. 2002).

Systematic coring of the Sokli site started in the early 1990s and, in 1996, two long cores (boreholes 900 and 901) were taken from the central part of the Sokli basin. The cores ( $2 \mathrm{~m}$ length, $4 \mathrm{~cm}$ diameter) were taken using a hydraulic piston corer designed by the Geological Survey of Finland, which was driven into the sediment by vibration. Lithological analysis of these cores showed major gaps in the sequence, for instance between the OIS-5e (or Eemian) interglacial sediments and the OIS-3 interstadial deposits (Helmens et al. 2000). In 2002, the Sokli A- and B-series were taken at a distance of 1-2 $\mathrm{m}$ from boreholes $900 / 901$ in an attempt to close the major gaps in the former cores.

\section{Borehole-stratigraphy of the Sokli B-series}

The Sokli B-series covers a depth of $26 \mathrm{~m}$ and shows only minor gaps in the sequence corresponding to the coarsest sediment layers, where drilling through coarse sands and gravels was difficult. Using both radiocarbon and optically stimulated luminescence (OSL) dating techniques, and using the pollen assemblages of the lowermost sediments to identify the OIS-5e (or Eemian) deposits, a chronology was established for the Sokli B-series (Helmens et al. 2007).

A simplified lithology for Borehole Sokli B-series is shown in Fig. 2. Nine Late-Quaternary stratigraphic units (SU) are distinguished (Helmens et al. 2007) the lowermost $5 \mathrm{~m}$ of sediment, consisting of diatom gyttja, and was formed during OIS-5e. Above $21 \mathrm{~m}$ core depth, a gravelly deposit (lower part of SU-2) with a fluvial origin is present. The upper part of SU-2 consists of a $2 \mathrm{~m}$ thick sand/silt sequence, showing parallel laminae that could have formed either in a low-energetic fluvial system or in a shallow lake environment. The minerogenic sediments of SU-2 grade into a thick laminated gyttja deposit, which, in its upper parts, is interlayered with

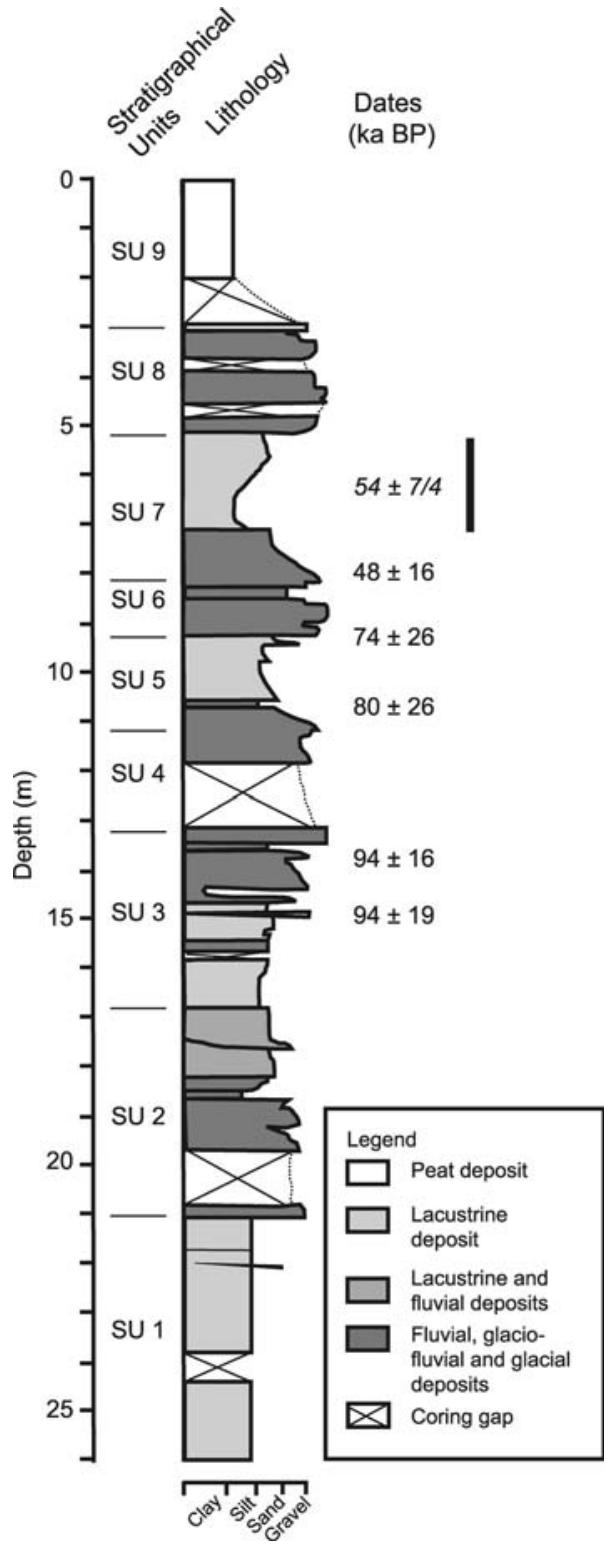

Fig. 2 Simplified lithological column of Borehole B-series at Sokli, with absolute age determinations (OSL-dates and uncorrected ${ }^{14} \mathrm{C}$-date (in italic)) and stratigraphical units (SU). The black bar to the right of the sediment-column represents the Tulppio interstadial (see text for description)

sand and gravel (SU-3). The OSL-dates, as well as the stratigraphy, indicate an age of OIS-5d and OIS$5 c$ for SU-2 and 3 respectively.

At $13.4 \mathrm{~m}$ core depth, a $2 \mathrm{~m}$ thick diamict deposit was recovered (SU-4). These glacially deposited materials correlate with OIS-5b. The overlying icemarginal gravels and sands, grading into laminated 
sands and silts and then into laminated sandy gyttja (SU-5), and are correlated to OIS-5a.

The till deposits of SU-6 (8.1-9.5 m core depth) represent the second phase of glaciation at the Sokli site. The till is overlain by glacio-fluvial sediments and thereafter by a $2 \mathrm{~m}$ thick minerogenic lacustrine deposit (SU-7). The sediments of this limnic deposit first become finer up the sequence, followed by a coarsening upwards, and are finally overlain by another till deposit (SU-8). The OSL-dates, the (uncalibrated) radiocarbon date and the stratigraphy indicate an age of OIS-4, early OIS-3 and OIS-3/OIS- 2 for SU-6, 7 and 8 respectively. The top of the sedimentological record consists of glacio-fluvial sediments grading into a Holocene peat deposit (SU-9).

\section{Sedimentary record of SU-7}

In this study, a detailed analysis of the sediments of stratigraphic unit 7 (early OIS-3), which has been defined as the Tulppio Interstadial (Helmens et al. 2007), is presented. The lowermost sediments of SU7 are relatively coarse, low in organic content, and show no sedimentary structures. Gradually, the sediment transforms into clayey sediments with a slightly higher organic content. Between $6.85 \mathrm{~m}$ and $6.75 \mathrm{~m}$ core depth, millimeter-scale alterations between clayey and silty layers are observed in the sediments. These laminations increase in thickness upward, and continue to $5.9 \mathrm{~m}$ core depth. The sediments become coarser, containing a matrix of silts and, above $5.9 \mathrm{~m}$ core depth, of sands. Around $5.2 \mathrm{~m}$ core depth wood fragments are encountered in the core and, at $5.14 \mathrm{~m}$ core depth, a large pebble is present within the much finer matrix. The presence of this stone is probably the result of ice rafting, which brought coarse material into the low-energetic lake system and deposited so-called dropstones.

\section{Methods}

Chironomid analysis

The $2 \mathrm{~m}$ thick deposit (between $7.1 \mathrm{~m}$ and $5.1 \mathrm{~m}$ core depth) was subsampled in $5 \mathrm{~cm}$ thick slices. A total of 39 wet sediment samples (weight range: 3.65$38.54 \mathrm{~g}$ ) was used for chironomid analysis. To remove fine particles from the samples, the sediments were deflocculated in cold $10 \% \mathrm{KOH}$ for at least $4 \mathrm{~h}$ and subsequently rinsed through a $100 \mu \mathrm{m}$ sieve. Using a dissecting microscope, chironomid head capsules were hand-picked at $35 \times$ magnification using fine forceps and permanently mounted on glass slides using Euparal ${ }^{\odot}$ mounting medium. The chironomid head capsules were identified following Wiederholm (1983), Heiri et al. (2004), Makarchenko and Makarchenko (1999), Moller Pillot (1984), Schmid (1993), Rieradevall and Brooks (2001) and Oliver and Roussel (1983). A chironomid percentage diagram was constructed using the computer programs TILIA and TG.VIEW (Grimm 1991-2004). Zonation of the chironomid diagram was carried out using the optimal sum-of-squares partitioning method as implemented in the program ZONE (Lotter and Juggins 1991), the significant number of zones was assessed by a broken stick model (Bennett 1996).

\section{Temperature inference}

A Norwegian chironomid-temperature calibration data set was used as a modern analogue for our fossil chironomid assemblages. This training set contains 153 Norwegian lakes and spans a mean July air temperature range of $3.5-15.6^{\circ} \mathrm{C}$ (unpublished data; Brooks and Birks 2001). A 3-component weightedaveraging partial least squares (WA-PLS) model was selected as the inference model with the best predictive power, using mean July air temperatures as the response variable and chironomid taxa as the predictor variables. Using leave-one-out cross-validation (jackknifing), the predictive powers of the model were estimated (Birks 1995). Our inference model had a RMSEP of $1.01{ }^{\circ} \mathrm{C}$, an $r^{2}$ of 0.91 and a maximum bias of $1.05^{\circ} \mathrm{C}$. A bootstrap cross-validation with 499 cycles was performed to calculate sample-specific error estimates. Using the modern analogue technique described by Birks et al. (1990), the occurrence of non-analogues in the fossil samples was calculated, where "no close" or "no good" analogues with the modern data were defined as the cut-level of the 2 nd and 5th percentile of all chi-square distances in the modern calibration data. A cut-level of the 95th and the 90th percentile of the modern residual chi-square distances was used as an estimate of the fit of the fossil samples to temperature ("very poor" and "poor" 
respectively; Heiri et al. 2003a). The percentage of rare taxa in the fossil samples was calculated, where a rare taxon has a Hill's $\mathrm{N}_{2}$ (Hill 1973) of 5 or less in the modern data set. Brooks and Birks (2001) state that the temperature optima of taxa with a $\mathrm{N}_{2}>5$ in the modern data are likely to be reliably estimated, whereas taxa with $\mathrm{N}_{2} \leq 5$ are rare in the modern data, and the optima for these taxa are probably poorly estimated. The temperature inference model, the analogues and the percentage of rare taxa were calculated using $\mathrm{C}^{2}$ version 1.4.3 (Juggins 2003), and the modern residual chi-square distances using CANOCO version 4.0 (Ter Braak and Šmilauer 1998).

The lowermost samples (below $6.79 \mathrm{~m}$ core depth) show low numbers of chironomid head capsules, even after all available material was examined for chironomid remains. These samples were therefore lumped and used as a single sample in the numerical analyses.

\section{Results and ecological interpretation}

\section{Chironomid record}

A total of 65 chironomid taxa was identified in the Sokli sediments and a summarized chironomid sequence is presented in Fig. 3. The average count sum in the samples above $6.75 \mathrm{~m}$ core depth was 89 head capsules (hc) per sample (range: 54-199 hc), although fewer counts were present in the lowermost part of the profile $(2-24 \mathrm{hc})$. The high number of lacustrine taxa with a preference for littoral to sublittoral habitats suggests that throughout the record a shallow lake was present at the Sokli site. Four zones have been distinguished in the chironomid record.

\section{Zone S-Ch1 (7.10-6.71 m)}

Tanytarsus lugens-type, Microtendipes and Polypedilum nubeculosum-type were among the taxa that first appeared at Sokli, and might be considered the early colonisers of the newly formed lake at Sokli. The chironomid concentration does not rise above $1 \mathrm{hc} / \mathrm{g}$, possibly due to high sedimentation rates.

In the upper part of zone S-Ch1, count sums increase to values above 50, and Chironomus anthracinus-type (20\%), T. lugens-type (15-40\%) and Procladius $(10 \%)$ are the most abundant taxa. Both C. anthracinus-type and Procladius have a broad distribution along the temperature gradient in the Norwegian training set: Procladius has a large

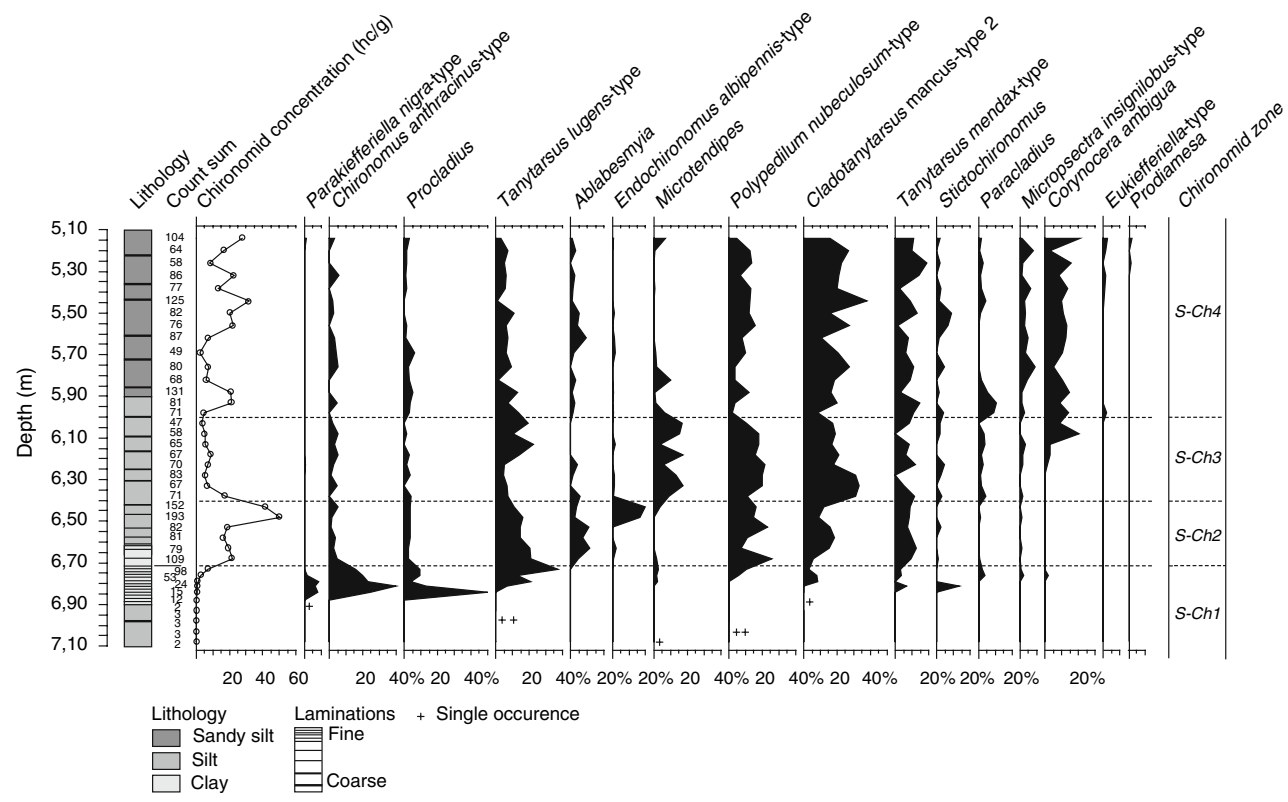

Fig. 3 Summary diagram showing selected chironomid taxa recovered from the Sokli sediments. Abundances for the individual taxa are given as percentages, the head capsule count-sum in numbers, and the chironomid concentration in the number of head capsules per gram wet sediment. The samples below $6.79 \mathrm{~m}$ core depth yielded limited numbers of chironomid head capsules, and individual findings are indicated with a (+) 
temperature tolerance, as it was found in lakes with mean July air temperatures ranging from $4.5^{\circ} \mathrm{C}$ to $16.0^{\circ} \mathrm{C}$. The abundances of $C$. anthracinus-type show a bimodal distribution in the modern calibration set, with a small optimum in abundances at $8.5^{\circ} \mathrm{C}$, and a large optimum in abundances around $14.6^{\circ} \mathrm{C}$. $T$. lugens-type, the third taxon to show high numbers, also has a large temperature-tolerance, but has been considered to be indicative for cool and oligotrophic conditions (e.g. Brooks 2006). All these taxa might be indicative of a relatively deep lake.

\section{Zone S-Ch2 $(6.71-6.40 \mathrm{~m})$}

The onset of zone S-Ch2 is indicated by a sharp increase in the concentration of chironomid remains, reaching values of $50 \mathrm{hc} / \mathrm{g}$ wet sediment. The assemblages are initially dominated by $T$. lugens-type, with abundances of $40 \%$ at the onset of this zone. Ablabesmyia shows its highest occurrences in the middle part of this zone (10\%). Toward the top of zone S-Ch2, the abundance of T. lugens-type declines and Tanytarsus mendax-type, Polypedilum nubeculosum-type and Cladotanytarsus mancus-type 2 become the dominant taxa. The latter two taxa (values above 20\%) are indicative of higher July air temperatures and the transition to a chironomid-assemblage that is dominated by these two taxa could be the result of a steadily increasing summer temperature at Sokli. At the end of zone S-Ch2 there is a peak in the occurrence of Endochironomus albipennis-type, which temporarily becomes the dominant taxon with an abundance of $20 \%$. This might indicate rising temperatures too, but could also be related to an increased nutrient availability in the lake.

\section{Zone S-Ch3 (6.40-6.00 m)}

Endochironomus albipennis-type and T. lugens-type show lower abundances at the onset of S-Ch3, while Microtendipes returns to the lake and reaches abundances of 5-15\%. P. nubeculosum-type and Cladotanytarsus mancus-type 2 remain the dominant taxa with an abundance of 20\% and 20-30\% respectively. Ablabesmyia shows declining abundances and temporarily disappears from the sequence during zone S-Ch3, while Corynocera ambigua appears in the middle of the zone. The concentration of chironomid head capsules is low throughout zone S-Ch3, between $5 \mathrm{hc} / \mathrm{g}$ and $10 \mathrm{hc} / \mathrm{g}$. The occurrence of Microtendipes could indicate temperatures that are best classified as intermediate to warm (Bedford et al. 2004; Brooks and Birks 2000) and the gradual warming trend that was observed in zone S-Ch2 was probably interrupted.

\section{Zone S-Ch4 (6.00-5.10 m)}

At the onset of S-Ch4, Microtendipes disappears from the sequence, whereas $C$. ambigua shows a constant abundance of $15 \%$. This latter species was formerly considered to be a true cold-water stenotherm, but those ideas have recently been questioned by Brodersen and Lindegaard (1999), as they found C. ambigua in temperature, eutrophic Danish lakes. In the Norwegian training set, this species has a narrow temperature tolerance $\left( \pm 1-2^{\circ} \mathrm{C}\right)$ with a temperature optimum of $9.9^{\circ} \mathrm{C}$. Paracladius shows its first phase of high abundance, reaching values of 10\%. At $5.83 \mathrm{~m}$ core depth, values of Paracladius decline and the head capsule density decreases to values below $10 \mathrm{hc} / \mathrm{g}$. In the uppermost part of the core, between $5.10 \mathrm{~m} 5.50 \mathrm{~m}$, this taxon reappears in the chironomid assemblage, but in much lower numbers. This genus is considered to be a true cold-water stenotherm, and its presence is possibly the result of a colder temperature at the study site.

At $5.60 \mathrm{~m}$ core depth, the head capsule density increases again to approximately $50 \mathrm{hc} / \mathrm{g}$. Stictochironomus reaches abundances of up to $10 \%$ in the upper part of the record. However, P. nubeculosumtype and Cladotanytarsus mancus-type 2 are still the dominant taxa in the assemblage. An interesting feature of the upper part of zone S-Ch4 is the occurrence of stream-inhabiting taxa such as Eukiefferiella and Prodiamesa.

The occurrence of taxa with a preference for lotic habitats, together with the coarser-grained sediment in this interval, suggests an increasing influence on the lake-catchment of proglacial streams from the nearby ice-sheet. The close proximity of the advancing ice sheet is further demonstrated by the uppermost part of the lacustrine deposit, which changes into a glacial till deposit, probably without a hiatus in the sedimentary sequence (Helmens et al. 2007). 
Quantitative climatic reconstruction

Figure 4 shows the reconstructed mean July air temperatures with the sample specific error bars. The reconstructed mean July air temperatures are relatively low $\left(12.0^{\circ} \mathrm{C}\right)$ for the lowermost part of the record but they increase steadily to values around $13.5^{\circ} \mathrm{C}$. At $6.30 \mathrm{~m}$ core depth, temperatures decline to values around $10.5-11.0^{\circ} \mathrm{C}$ after which they stabilise around $12.0-13.0{ }^{\circ} \mathrm{C}$ up to $5.30 \mathrm{~m}$ core depth. The uppermost three samples show a return to colder conditions with an inferred temperature of $11.5-12.0^{\circ} \mathrm{C}$. Since the reconstructed July air temperatures are not near the upper limit of the temperature range of the modern training set $\left(15.6^{\circ} \mathrm{C}\right)$, the influence of so-called edge effects (Ter Braak and Juggins 1993; Birks 1998) can be excluded. Furthermore, where under colder climatic conditions the biodiversity tends to be reduced and the same cold-adapted assemblage of chironomids might exist over a wide temperature range (Birks and Birks 2006), our reconstructed temperatures are in the intermediate to warm range and so are not likely to suffer from this problem.

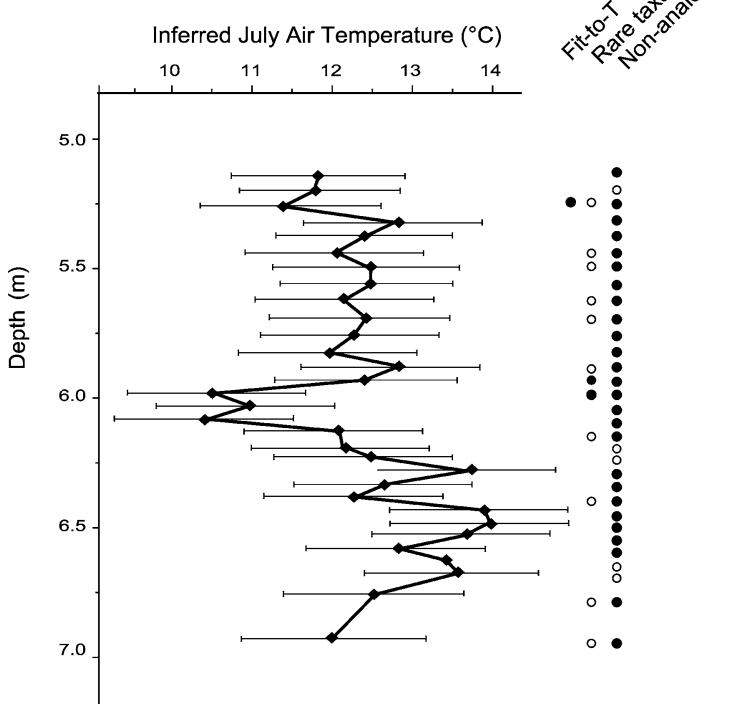

Fig. 4 Chironomid-inferred mean July air temperatures, and sample specific error-bars. The open circles indicate samples with no good analogues, and samples with more than 5\% abundance of that are taxa rare in the modern training set. The solid circles indicate samples with no close analogues, with more than $10 \%$ abundance of taxa that are rare in the modern training set, and samples with a poor fit to temperature
The cumulative abundance of the six taxa included in the fossil assemblages but absent from the modern calibration set is between $0.0 \%$ and $6.9 \%$ per sample, whereas on average $98.7 \%$ of the identified fossil chironomids were used to obtain palaeotemperature estimates. Most of the identified fossil chironomids were well-represented in the modern training set, as there are only 3 fossil samples that have an abundance of rare taxa higher than $10 \%$. These samples all have a high abundance of Paracladius, a taxon that in the modern training set has an effective number of occurrences (Hills $\mathrm{N}_{2}$ ) of 4.6, just below our threshold of 5 .

Only 1 sample shows a poor fit to temperature and not a single sample has a residual chi-square distance higher than the extreme $5 \%$ of the modern samples and therefore none is classified as having a "very poor" fit to temperature. The fossil sample that is classified as having a "poor fit" to temperature is situated in a part of the record where both the chironomid-assemblages as well as the reconstructed temperatures are stable.

No fossil sample has a close analogue in the modern data, and $75 \%$ of the fossil samples have no good analogues. This result is surprising, as all the dominant taxa of the fossil record are all wellrepresented in the Norwegian training set and the training set contains many shallow, macrophyte rich lakes that could potentially provide good analogues for the fossil chironomid-assemblages. Probably, the relative abundances of taxa in the fossil samples are not (well) reflected in the individual training set lakes. Although there are no close modern analogues in the training set, WA-PLS can perform relatively well in poor analogue situations (Birks 1998).

Since there is a good fit to temperature and a high number of fossil taxa that are well-represented in the modern training set, the inferred values are considered to be reliable given the properties of the modern calibration data.

\section{Discussion}

The results presented in this study show the first chironomid-derived palaeotemperature estimates for early OIS-3 in northwestern Europe. Our reconstructed temperatures are surprisingly high, considering that the deposits were formed during the last 
glacial. The highest reconstructed temperatures are as high as the current mean July air temperature $\left(13^{\circ} \mathrm{C}\right)$ at the study site, and even the lower reconstructed values of $10.5^{\circ} \mathrm{C}$ are temperatures that are currently found in northern parts of Finland and Norway (Drebs et al. 2002).

Chironomid studies on both late-glacial and Holocene sediments have produced inferred temperature reconstructions that were in concurrence with other proxy-based temperature estimates (e.g. Heiri and Millet 2005; Magny et al. 2006), but also reconstructions that showed discrepancies between different sites (e.g. Velle et al. 2005) or with reconstructions based on different proxies (e.g. Birks and Ammann 2000). Larocque and Hall (2003) elegantly show that in their study there was a close similarity between measured and chironomid-inferred summer temperatures, but they also state that on longer temporal timescales, this relationship might not remain constant. Therefore, each record showing midge-palaeotemperature reconstructions must be interpreted cautiously, and in the context of all palaeoenvironmental data available (Heiri and Lotter 2005; Walker and Cwynar 2006).

Below, we discuss mechanisms that could potentially have influenced our chironomid-inferred temperatures. Second, the chironomid-based results are compared to other proxy-based results from Sokli, and to model-based July air temperature reconstructions for north Finland. Finally, our results will be compared to other temperature records inferred from terrestrial sites in northwestern Europe.

\section{Sampling design}

The fossil chironomid remains recovered in the sediments from the Sokli site are surprisingly well preserved, considering that an ice-sheet has overridden these deposits. Identification of the fossil material was possible to a degree of taxonomic resolution similar to the calibration set. Great care was taken to retrieve the core from the central part of the Sokli basin (Helmens et al. 2000, 2007) as was done during the sampling of the lakes in our modern calibration dataset, and to prevent any influence of within-lake variability in chironomid-inferred temperatures as presented in Heiri et al. (2003b).
Lake depth

Walker and Cwynar (2006) state that the influence of lake depth on palaeotemperature inferences poses a problem that deserves more attention. Deep, thermally stratified lakes may provide habitats suitable for cold-stenothermous midges, whereas shallow lakes from the same region will not support these species. Palaeotemperature inferences from deep lakes might therefore result in lower temperatures than those inferred from the shallower sites. Both the chironomid-assemblages as well as the botanical macro-remains from the lacustrine sediments of SU7 suggest that a shallow lake was present at the study site throughout the period considered, although the lake might have been relatively deeper during zone $\mathrm{S}$-Ch1. This is also suggested by preliminary diatom results (unpublished data). As no drastic increase in littoral macrophyte taxa such as Carex spp. is reconstructed (unpublished data) we exclude a major influence of lake infilling on the lacustrine habitats available for chironomids.

\section{Dispersion}

Velle et al. (2005) conclude that during the Holocene, mobility may not have been a limiting factor for the distribution of chironomids on the Scandinavian mainland. However, during OIS-3 there was a limited-sized ice-sheet situated close to our study site, possibly forming a major barrier for dispersal from the west or south. The lower sediment samples from our record (below $6.79 \mathrm{~m}$ core depth) show a low Hill's $\mathrm{N}_{2}$-diversity. However, the samples above $6.79 \mathrm{~m}$ core depth show relatively high $\mathrm{N}_{2}$-diversity, suggesting that after $6.79 \mathrm{~m}$ core depth the colonisation of this lake has not been a problem for a wide range of taxa. Even a species with a limited mobility such as C. ambigua (Brodersen and Lindegaard 1999) reached the Sokli basin quickly with respect to the introduction of other chironomid taxa.

Several taxa that reach high abundances only at a later stage in the record already have single occurrences in the lower parts of the record, before finally establishing themselves during a later stage (see for instance Paracladius). Therefore, local climate or habitat conditions rather than a restricted dispersion 
have most likely been the controlling factor for the composition of the chironomid assemblages.

Decoupling of water temperature and air temperature

Many modern training sets have been designed with the specific goal of providing a tool for reconstructing mean July air temperatures. This however does not mean that the authors assume that the chironomid fauna responds exclusively to air temperature (Birks 1998). In fact, it is likely that chironomids respond to both air and water temperature, as water temperature influences the development of the midges during the relatively long larval stage, whereas air temperature has a direct influence only on the survival and distribution of the winged, short-lived adult stage (Brooks and Birks 2001).

Livingstone and Lotter (1998) found a strong correlation between mean July lake water and air temperatures in Switzerland. However, there are several potential decoupling mechanisms between July air temperature and water temperature, for instance, an increased influence of winter precipitation in the form of snow on the temperature of the lake water (Birks and Birks 2006), or the influence of glacier-fed streams on a lake (Brooks and Birks 2001).

In order to investigate whether these potential mechanisms played a role in the former lake, or whether past changes in nutrient availability have influenced the chironomid-based temperature inferences, the application of a single proxy will not suffice. Multi-proxy studies providing multiple lines of evidence for possible changes in climate or environment will help to identify factors influencing the composition of fossil chironomid assemblages.

Other proxy-records from the Sokli study-site and comparison with model results

In the Sokli-project, botanical and zoological macroremain analyses were carried out as an independent assessment of local climate conditions. Palaeotemperature estimates were made based on the botanical taxa by using the climate indicator plant species method (sensu Iversen 1954; Kolstrup 1980). Certain plants require certain minimum mean summer temperatures to flower and reproduce and the relationship between the geographical limit of plant distribution and temperature can be used to reconstruct past minimum temperatures based on fossil records of plant remains.

Macroremains of Potamogeton mucronatus-type are found in Zone S-Ch2, and oogonia of Characeae are abundant in this zone as well. In the remaining part of the sediment sequence, macro-remains of aquatic plants are absent (unpublished data). Preliminary pollen results reveal that throughout the record an aquatic macrophyte vegetation was present consisting of taxa such as Isoetes, Myriophyllum spicatum and Potamogeton. No major trends are visible in the abundances of aquatic plant pollen, and we therefore do not assume major changes in available micro-habitats for chironomids as a result of changing aquatic vegetation.

The quantitative temperature record inferred from the botanical macro-remains shows a similar temperature trend to the chironomid-based temperaturereconstruction. The aquatic macro-remains reconstruct the warmest interval to be between $6.7 \mathrm{~m}$ and $6.4 \mathrm{~m}$ core depth (Fig. 5). The organic content of the sediment is also highest during this part of the record, although variations in organic matter are comparatively low in the entire profile. As the reconstructed temperatures based on botanical macro-remains represent minimum mean July air temperatures instead of the mean July air temperature-estimates that are obtained through the analysis of chironomid remains, the macro-remain based palaeotemperatures are slightly lower throughout the record.

A high number of statoblasts of the bryozoan species Fredericella indica is recorded in the interval between $6.7 \mathrm{~m}$ and $6.4 \mathrm{~m}$ core depth as well. Instead of being indicative of a minimum mean July air temperature, it is known from modern observations that this species is most common in lakes with water temperatures between $11^{\circ} \mathrm{C}$ and $15^{\circ} \mathrm{C}$ (Økland and Økland 2001), which corresponds well with the temperatures inferred from the chironomid remains. Increasing wetland vegetation fringing the lake and deposition of laminated clay and silts may have hampered a further expansion of Fredericella indica after $6.4 \mathrm{~m}$ core depth, as it prefers stony shores and avoids lakes with soft sediments and vegetation rich in Sphagnum (Økland and Økland 2001). 

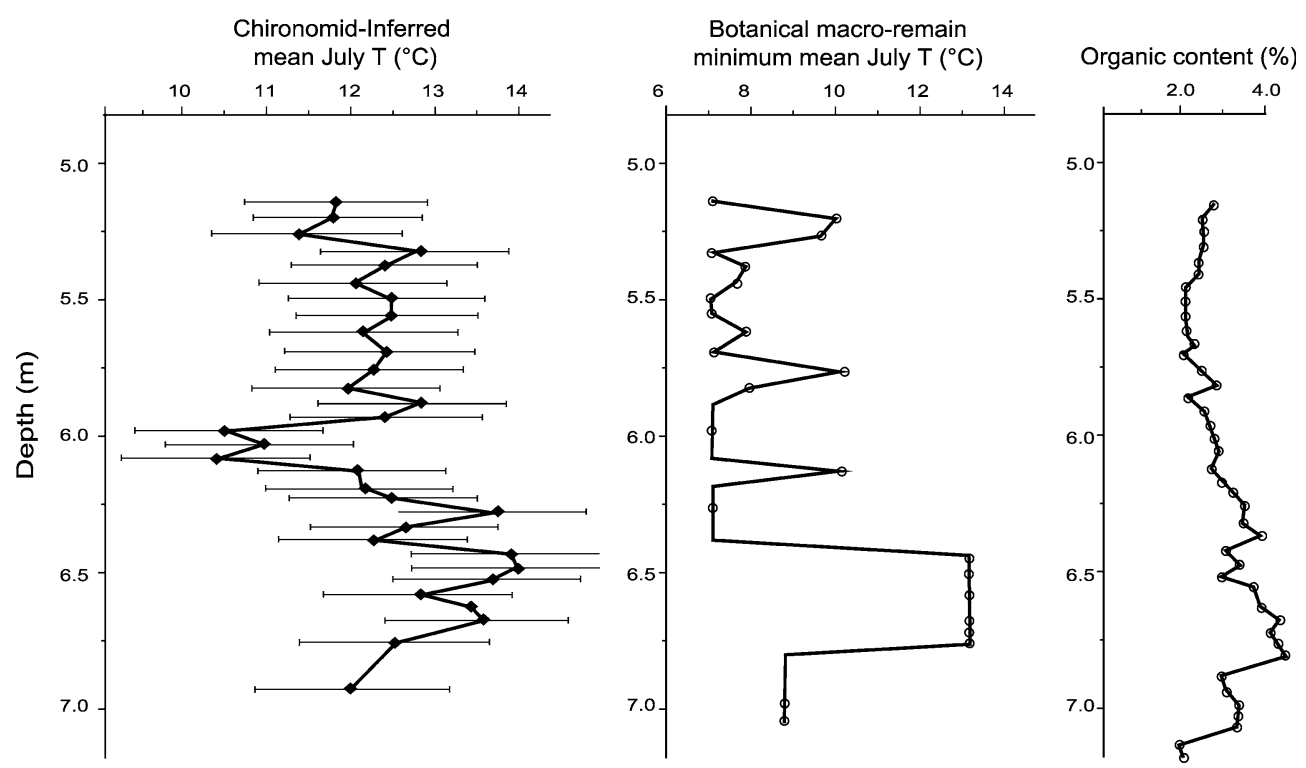

Fig. 5 Chironomid-inferred mean July air temperature, macro-remain inferred minimum mean July air temperature and organic matter content of the sediment

Because of the presence of a reduced ice sheet over Scandinavia during OIS-3, the atmospheric circulation over Northeast Finland must have been different from the current circulation pattern. Using the ECBilt-CLIO-VECODE coupled atmosphereocean-vegetation model, circulation patterns for interstadial conditions during OIS-3 have been reconstructed (Helmens et al. accepted). These climate model runs show a stable circulation pattern in which dry, northerly winds advect dry air to northeast Finland. As summer-insolation was relatively high (even slightly higher than today), and reconstructed soil moisture in the model is low, there is a relatively high amount of solar energy available to heat up the surface. This results in model-based temperature reconstructions in the order of $13^{\circ} \mathrm{C}$, similar to our reconstructed range of $10.5-14^{\circ} \mathrm{C}$.

\section{Comparison with other NW European sites}

The climate model runs performed by Helmens et al. (in press) suggest that atmospheric circulation patterns over the UK were similar to those at the Sokli site, i.e. dry air that was advected from the ice-sheet to the adjacent land. Several terrestrial records registering the early part of OIS-3 are available from central and southern England (Coope 2002). Reconstructed summer temperatures, based on fossil coleopteran (beetle) assemblages, show that the climate during OIS-3 was probably temperate and oceanic in England with mean monthly July temperatures reaching levels at least as warm as those of the present day (Coope 2002).

In contrast to the locations southwest (England) and northeast (Sokli) of the former ice-sheet, the model results by Helmens et al. (in press) indicated that temperatures in locations south of the ice sheet (i.e. Germany) should be lower than those of the present day. Analysis of fossil coleopteran assemblages from the Oerel-site (northern Germany) suggested a mean July temperature of $12^{\circ} \mathrm{C}$ at this more southerly location (Behre et al. 2005). This cooler temperature is indeed in contrast with the high temperatures reconstructed at Sokli and in the British Isles.

In eastern Germany, a location also south of the fossil ice-sheet but located further away from the icefront than the Oerel-site, lacustrine sediments from the opencast lignite mines of the Niederlausitz area were used to obtain pollen- and macro-remain based minimum mean July temperature estimates (Bos et al. 2001; Kasse et al. 2003). Minimum mean summer temperatures were at least $12-13^{\circ} \mathrm{C}$ at this 
location. This is cooler than the present day temperature at this location $\left(17-18^{\circ} \mathrm{C}\right)$, which is in line with the results from the Oerel site. In conclusion, the same temperature pattern can be derived from the few available records for OIS-3 as has been suggested based on the climate model simulations of Helmens et al. (in press).

\section{Conclusions}

A unique fossil-rich lacustrine deposit, dated to the earlier part of OIS-3, with little post-depositional disturbance, was retrieved from the high-latitudinal Sokli-site. Analysis of this sequence showed changing concentrations of chironomid remains and a dynamic composition of the chironomid assemblages throughout the record:

(1) The high number of lacustrine taxa with a preference for littoral to sublittoral habitats suggests that a shallow lake must have existed at the Sokli study site.

(2) Using a Norwegian chironomid-based temperature inference model, palaeotemperature estimates were derived from the fossil chironomid-assemblages. The reconstructed mean July air temperatures are in the range of $10.5-14^{\circ} \mathrm{C}$, surprisingly high considering the current mean July air temperature of $13^{\circ} \mathrm{C}$ at the Sokli study site.

(3) Botanical and zoological macro-remains of aquatic taxa, encountered in the Sokli sediments, provide independent evidence for a period of high (minimum) July air temperatures, in agreement with the chironomid-based inferences.

(4) The warm July air temperatures reconstructed for Sokli during OIS-3 are in agreement with modelled results for interstadial conditions in northeast Finland.

To our knowledge there exist no similar studies providing quantitative temperature reconstructions for high-latitudinal continental sites in Europe for the earlier part of OIS-3. At the Sokli study site, chironomid-remains provided independent evidence for high summer temperatures in northeast Finland during early OIS-3.
Acknowledgements We would like to thank Mrs. Marjut Nyman for providing unpublished data for comparison, the Geological Society of Finland for coring, Ian Walker and Mrs. Christina Bleskie for introducing $\mathrm{KH}$ to chironomid analysis, and Jef Vandenberghe for constructive critisism on an earlier draft of the manuscript. Pete Langdon and an anonymous reviewer are thanked for their useful suggestions. This paper is a contribution to the RESOLuTION-project (ESF Eurocores program). The research project of S.E. is supported by the Council of Earth and Life Sciences of the Netherlands Organization for Scientific Research (grant-no 813.02.004). This is Netherlands Research School of Sedimentary Geology publication 20070605.

\section{References}

Barley EM, Walker IR, Kurek J, Cwynar LC, Mathewes RW, Gajewski K, Finney BP (2006) A northwest North American training set: distribution of freshwater midges in relation to air temperature and lake depth. J Paleolimnol 36:295-314

Bedford A, Jones RT, Lang B, Brooks SJ, Marshall JD (2004) A late-glacial chironomid record from Hawes Water, northwest England. J Quatern Sci 19:281-290

Behre KE, Hölzer A, Lemdahl J (2005) Botanical macroremains and insects from the Eemian and Weichselian site of Oerel (northwest Germany) and their evidence for the history of climate. Veg Hist Archaeobot 14:31-53

Bennett KD (1996) Determination of the number of zones in a biostratigraphical sequence. New Phytol 132:155-170

Birks HJB (1995) Quantitative palaeoenvironmental reconstructions. In: Maddy D, Brew JJ (eds) Statistical modelling of quaternary science data. Quaternary Research Association, Cambridge, pp 161-254

Birks HJB (1998) Numerical tools in palaeolimnology-progress, potentialities, and problems. J Paleolimnol 20:307332

Birks HH, Ammann B (2000) Two terrestrial records of rapid climatic change during the glacial-Holocene transition (14,000-9,000 calendar years B.P.) from Europe. Proc Natl Acad Sci 97:1390-1394

Birks HH, Birks HJB (2006) Multi-proxy studies in palaeolimnology. Veg Hist Archaeobot 15:235-251

Birks HJB, Line JM, Juggins S, Stevenson AC, Ter Braak CJF (1990) Diatoms and $\mathrm{pH}$ reconstruction. Philos Trans R Soc Lond B 327:263-278

Bos JAA, Bohncke SJP, Kasse C, Vandenberghe J (2001) Vegetation and climate during the Weichselian early glacial and Pleniglacial in the Niederlausitz, eastern Germany-macrofossil and pollen evidence. J Quatern Sci 16:269-289

Brodersen KP, Lindegaard C (1999) Mass occurrence and sporadic distribution of Corynocera ambigua Zetterstedt (Diptera, Chironomidae) in Danish lakes. Neo- and palaeolimnological records. J Paleolimnol 22:41-52

Brooks SJ (2006) Fossil midges (Diptera: Chironomidae) as palaeoclimatic indicators for the Eurasian region. Quatern Sci Rev 25:1894-1910 
Brooks SJ, Birks HJB (2000) Chironomid-inferred late-glacial air temperatures at Whitrig Bog, south-east Scotland. J Quatern Sci 15:759-764

Brooks SJ, Birks HJB (2001) Chironomid-inferred air temperatures from Lateglacial and Holocene sites in northwest Europe: progress and problems. Quatern Sci Rev 20:1723-1741

Cane MA, Braconnot P, Clement A, Gildor H, Joussaume S, Kageyama M, Khodri M, Paillard D, Tett S, Zorita E (2006) Progress in paleoclimate modeling. J Climate 19:5031-5057

Coope GR (2002) Changes in the thermal climate in northwestern Europe during marine oxygen isotope stage 3, estimated from fossil insect assemblages. Quatern Res 57:401-408

Cubasch U, Meehl G, Boer GJ, Stouffer RJ, Dix M, Noda A, Senior CA, Raper S, Yap KS (2001) Projections of future climate change. In: Houghton JT, Ding Y, Griggs DJ, Noguer M, Van der Linden PJ, Dai X, Maskell K, Johnson CA (eds) Climate change 2001: the scientific basis. Contribution of working group I to the third assessment report of the intergovernmental panel on climate change. Cambridge University Press, Cambridge, pp 525-582

Dansgaard W, Johnsen SJ, Clausen HB, Dahl-Jensen D, Gundestrup NS, Hammer CU, Hvidberg CS, Steffensen JP, Sveinbjörndottir AE, Jouzel J, Bond G (1993) Evidence for general instability of past climate from a 250-kyr icecore record. Nature 364:218-220

De Beaulieu J-L, Reille M (1992). The last climatic cycle at La Grande Pile (Vosges, France) a new pollen profile. Quatern Sci Rev 11:431-438

Drebs A, Nordlund A, Karlsson P, Helminen J, Rissanen P (2002) Climatological statistics of Finland 1971-2000. Finnish Meteorological Institute, Helsinki, 99 pp

Eggermont H, Heiri O, Verschuren D (2006) Fossil Chironomidae (Insecta: Diptera) as quantitative indicators of past salinity in African Lakes. Quatern Sci Rev 25:19661994

Grimm EC (1991-2004) TILIA, TILA.GRAPH, and TGView. Illinois State Museum, Research and Collections Center, Springfield, USA http://www.demeter.museum.state.il. us/pub/grimm/

Heiri O, Birks HJB, Brooks SJ, Velle G, Willassen E (2003b) Effects of within-lake variability on fossil assemblages on quantitative chironomid-inferred temperature reconstructions. Palaeogeogr Palaeoclimatol Palaeoecol 199:95-106

Heiri O, Ekrem T, Willassen E (2004) Larval head capsules of European Micropsectra, Paratanytarsus and Tanytarsus (Diptera: Chironomidae: Tanytarsini). Version 1.0. http://www.bio.uu.nl/ palaeo/Chironomids/Tanytarsini/ intro.htm

Heiri O, Lotter AF (2005) Holocene and Lateglacial summer temperature reconstruction in the Swiss Alps based on fossil assemblages of aquatic organisms: a review. Boreas 34:506-516

Heiri O, Lotter AF, Hausmann S, Kienast F (2003a) A chironomid-based Holocene summer air temperature reconstruction from the Swiss Alps. Holocene 13:477-484

Heiri O, Millet L (2005) Reconstruction of Late Glacial summer temperatures from chironomid assemblages in Lac Lautrey (Jura, France). J Quat Sci 20:33-44
Helmens KF, Bos JAA, Engels S, Van Meerbeeck C, Bohncke SJP, Renssen H, Heiri O, Brooks SJ, Seppä H, Birks HJB, Wohlfarth B (in press) Ice-free conditions and present-day temperatures during the last glacial at $50 \mathrm{ka}$ in the central area of the Scandinavian glaciations. Geology

Helmens KF, Johansson PW, Räsänen ME, Alexanderson H, Eskola KO (2007) A series of ice-free intervals continuing into MIS 3 recorded in the central area of Fennoscandian glaciation: late Quaternary climate-stratigraphy at Sokli. Bull Geol Soc Finl 79:17-39

Helmens KF, Räsänen $\mathrm{ME}$, Johansson $\mathrm{PW}$, Jungner $\mathrm{H}$, Korjonen K (2000) The last interglacial-glacial cycle in NE Fennoscandia: a nearly continuous record from Sokli (Finnish Lapland). Quatern Sci Rev 19:1605-1623

Hill MO (1973) Diversity and evenness: a unifying notation and its consequences. Ecology 54:427-432

Huijzer B, Vandenberghe J (1998) Climatic reconstruction of the Weichselian Pleniglacial in northwestern and central Europe. J Quatern Sci 13:391-417

Ilyashuk EA, Ilyashuk BP, Hammarlund D, Larocque I (2005) Holocene climatic and environmental changes inferred from midge records (Diptera: Chironomidae, Chaoboridae, Ceratopogonidae) at Lake Berkut, southern Kola Peninsula, Russia. Holocene 15:897-914

Iversen J (1954) The Late-Glacial flora of Denmark and its relation to climate and soil. Danm Geol Undersøg 2:88119

Johnsen SJ, Clausen HB, Dansgaard W, Fuhrer K, Gundestrup N, Hammer CU, Iversen P, Jouzel J, Stauffer B, Steffensen JP (1992) Irregular glacial interstadials recorded in a new Greenland ice core. Nature 359:311-313

Juggins S (2003) $C^{2}$ user guide. Software for ecological and palaeoecological data analysis and visualisation. University of Newcastle, Newcastle upon Tyne, UK

Kageyama M, Laine A, Abe-Ouchi A, Braconnot P, Cortijo E, Crucifix M, De Vernal A, Guiot J, Hewitt CD, Kitoh A, Kucera M, Marti O, Ohgaito R, Otto-Bliesner B, Peltier WR, Rosell-Mele A, Vettoretti G, Weber SL, Yu Y, MARGO Project Members (2006) Last Glacial maximum temperatures over the North Atlantic, Europe and western Siberia: a comparison between PMIP models, MARGO sea-surface temperatures and pollen-based reconstructions. Quatern Sci Rev 25:2082-2102

Kasse C, Vandenberghe J, van Huissteden J, Bohncke SJP, Bos JAA (2003) Sensitivity of Weichselian fluvial systems to climate change (Nochten mine, eastern Germany). Quatern Sci Rev 22:2141-2156

Kolstrup E (1980) Climate and stratigraphy in Northwestern Europe between 30,000 BP and 13,000 BP, with special reference to The Netherlands. Meded Rijks Geol Dienst 32:181-253

Larocque I, Hall RI (2003) Chironomids as quantitative indicators of mean July air temperature: validation by comparison with century-long meteorological records from northern Sweden. J Paleolimnol 29:475-493

Livingstone DM, Lotter AF (1998) The relationship between air and water temperatures in lakes of the Swiss Plateau: a case study with palaeolimnological implications. J Paleolimnol 19:181-198

Lotter AF, Juggins S (1991) POLPROF, TRAN and ZONE: programs for plotting, editing and zoning pollen and 
diatom data. Inqua-subcommission for the study of the Holocene, Working Group on Data-Handling Methods. Newsletter 6:4-6

Magny M, Aalbersberg G, Bégeot C, Benoit-Ruffaldi P, Bossuet G, Disnar JR, Heiri O, Laggoun-Defarge F, Mazier F, Millet L, Peyron O, Vannière B, Walter-Simonnet AV (2006) Environmental and climatic changes in the Jura mountains (eastern France) during the Lateglacial-Holocene transition: a multi-proxy record from Lake Lautrey. Quatern Sci Rev 25:414-445

Makarchenko EA, Makarchenko MA (1999) Chironomidae. In: Tsalolikhin SJ (ed) Key to freshwater invertebrates of Russia, adjacent lands. Zoological Institute RAS, St. Petersburg, pp 670-857

Moller Pillot HKM (1984) De larven der nederlandse Chironomidae (Diptera) (Inleiding, Tanypodinae \& Chironomini). Nederlandse Faunistische Mededelingen 1A

Økland KA, Økland J (2001) Freshwater bryozoans (Bryozoa) of Norway II: distribution and ecology of two species of Fredericella. Hydrobiologia 459:103-123

Oliver DR, Roussel ME (1983) The insects and arachnids of Canada, part 11: the genera of larval midges of CanadaDiptera: Chironomidae. Agriculture Canada Publication 1746, $263 \mathrm{pp}$

Quinlan R, Smol JP (2001) Chironomid-based inference models for estimating end-of-summer hypolimnetic oxygen from south-central Ontario shield lakes. Freshw Biol 46:1529-1551

Rieradevall M, Brooks SJ (2001) An identification guide to subfossil Tanypodinae larvae (Insecta: Diptera: Chironomidae) based on cephalic setation. J Paleolimnol 25:81-99

Schmid PE (1993) A key to the larval Chironomidae and their instars from Austrian danube region streams and rivers with particular reference to a numerical taxonomic approach. Part I. Diamesinae, Prodiamesinae and Orthocladiinae. Wasser und Abwasser Supplement 3/93, 514 pp
Ter Braak CJF, Juggins S (1993) Weighted averaging partial least squares regression (WA-PLS): an improved method for reconstructing environmental variables from species assemblages. Hydrobiologia 269/270:485-502

Ter Braak CJF, Šmilauer P (1998) CANOCO reference manual and user's guide to Canoco for windows. Wageningen, Centre for Biometry Wageningen, $352 \mathrm{pp}$

Vandenberghe J, Coope R, Kasse C (1998) Quantitative reconstructions of palaeoclimates during the last interglacial-glacial in western and central Europe: as introduction. J Quatern Sci 13:361-366

Van der Hammen Th, Maarleveld GC, Vogel JC, Zagwijn W (1967) Stratigraphy, climatic succession and radiocarbon dating of the last glacial in the Netherlands. Geol Mijnb 46:79-95

Velle G, Brooks SJ, Birks HJB, Willassen E (2005) Chironomids as a tool for inferring Holocene climate: an assessment based on six sites in southern Scandinavia. Quatern Sci Rev 24:1429-1462

Voelker AHL, workshop participants (2002) Global distribution of centennial-scale records for Marine Isotope Stage (MIS) 3: a database. Quatern Sci Rev 21:1185-1212

Walker IR, Cwynar LC (2006) Midges and palaeotemperature reconstruction-the North American experience. Quatern Sci Rev 25:1911-1925

Walker IR, Smol JP, Engstrom DR, Birks HJB (1991) An assessment of Chironomidae as quantitative indicators of past climatic change. Can J Fish Aquat Sci 48:975-987

Wiederholm T (1983) Chironomidae of the Holarctic region. Keys and diagnoses. Part I. Larvae. Entomol Scand 19:1457

Woodward CA, Shulmeister J (2006) New Zealand chironomids as proxies for human-induced and natural environmental change: transfer functions for temperature and lake production (chlorophyll a). J Paleolimnol 36:407-429 